\title{
Spatial variation of basin supply as a factor of water quality in a shallow, flow-through lake
}

\author{
Beata Ferencz ${ }^{1}$, Jarosław Dawidek ${ }^{2}$ \\ ${ }^{1}$ Departament of Hydrobiology, University of Life Sciences, Akademicka 13, 22-950 Lublin, Poland, e-mail: beata.ferencz@up.lublin.pl \\ ${ }^{2}$ Departament of Hydrology, University of Maria Curie-Skłodowska, Akademicka 19, 20-033 Lublin, Poland, \\ e-mail: jaroslaw.dawidek@poczta.umcs.lublin.pl
}

\begin{abstract}
Lake Syczyńskie is a water body that represents a group of the smallest Łęczna-Włodawa Lakes. The lake is supplied with waters from the four streams, while the outlet from the lake is directed into the Swinka River. The residence time of water is very short in Lake Syczyńskie. A role and variation of water supply from the catchment area were calculated using the mean seasonal loads transported from lakes sub-basins. A range of ionic migration into the basin of the lake was presented by means of daily and five-day radiuses. Among all inflows, C2 and C4 streams that drained Chełm Hills structure, were the most stable ones. The C3 stream that drained lake vicinity, was less important in shaping the quality of the lake water, while stream $\mathrm{C} 1$ was the one with a wide range of seasonal loads inconstancy. The highest fluviodynamic and matter transport occurred during the cold season. However, during the warm season in-lake processes were significant in terms of shaping the quality of lake water.
\end{abstract}

Key words: ionic translocation, water exchange, fluviodynamic, matter transport

\section{Introduction}

Water conditions are the most important factors which shaping both, qualitative and quantitative lake functioning. The role of hydrosphere is easier to quantify under very stable physical-geographical conditions of the catchment area. In catchments areas with diverse surface morphology this role depends on many complex factors. Among Łęczna-Włodawa Lakes there are many water bodies with dual catchment areas, built with both, cretaceous rocks in the upper part and silt or organogenic rocks in the lake vicinity. According to Chałubińska and Wilgat division of Lubelszczyzna Region (1954), the catchment area of Lake Syczyńskie is located in a border zone between Polish Lowlands and Chełm Hills. Its area is an example of a duality of the natural conditions. Hydrochemical water conditions are determined by water distribution as well as by the phases and forms of water supply. Water quality results from many complex factors. However, in hydrology water quality is often understood as a nutrient content (Schwarz et al. 2004). A significant changeability, resulted from means and quantity of water supply, is observed in the shallow lakes. The capture of these changes is possible only in the catchments where research is being done continuously (Hwang et al. 2000; Nayak et al. 2004; Vicente et al. 2006).

\section{Study area}

A clear duality of the catchment area of Lake Syczyńskie results from its location between two physiographically distinct units. The catchment (2.66 $\mathrm{km}^{2}$ ) was drained by four streams, one of which (C2) was perennial, two ( $\mathrm{C} 1$ and $\mathrm{C} 4)$ were intermittent, and one (C3) was ephemeral (Fig. 1). The lake outlet directs water to the south-west of the catchment, to the Świnka River. Water conditions of the parallel elongated area were complicated and modified by agricultural landscape (79.5\% arable lands) and altitudes that reached 50 meters. The upper, eastern part of the catchment is built of cretaceous rocks (Chełm Hills), while the northern part is built of silicate and organogenic rocks (Polesie). Territorial research was done during water years 2007-2009. 


\section{Methods}

Both, territorial research and computer data processing (using GIS software) have been used. The rate of water flow was measured using Nautillus 2000. Moreover, the daily water levels of the lake and streams were observed. Morphometric parameters of the lake were carried out three times, during extremely different basin capacity. The hydrochemical analyses of macro elements were carried out in the laboratory of the Department of Hydrology, using ionic chromatograph JC MIC 3. Water samples were analyzed for the ions originated from the geological structure, human activity (anthropogenic ions) and biogens. The visualization of sub-catchments hydrogeochemical potential was done using GIS and Didger software. The duality of the process that shapes lake water quality was assumed. The first part of this process was a supply area and its morphological features, (e.g. water circulation, catchment relief) while the second one physical-chemical basin processes. The role of sub-catchments influence on Lake Syczyńskie water quality was estimated using mean seasonal values of ionic load [ $\mathrm{kg}$ season ${ }^{-1}$ ], based on the daily stream flows. A quantity of the dissolved mineral matter has been presented using mean seasonal radiuses of supplied matter, calculated in relation to the lake area. The assumption that the main type of matter translocation is a piston-flow was made (Witczak and Adamczyk 1994). Moreover, homogenous of radiuses deployment in all directions was assumed, as from the streams mouth. A vector of the matter supply (base of a cone) was calculated comparing a part of the lake basin to the cone with different altitudes: $0.5,1.0,1.5$, 2.0, $2.5 \mathrm{~m}$. A tangent of the altitude and radius angle must have been equal to real angle of the slope of lake basin (calculated using bathymetric chart). In order to present a dynamic of the supply process, daily and five-day radiuses was calculated for every stream. To avoid a radiuses superposition problem, the five-day period was the longest one, taking into consideration the quantity of dissolved matter.

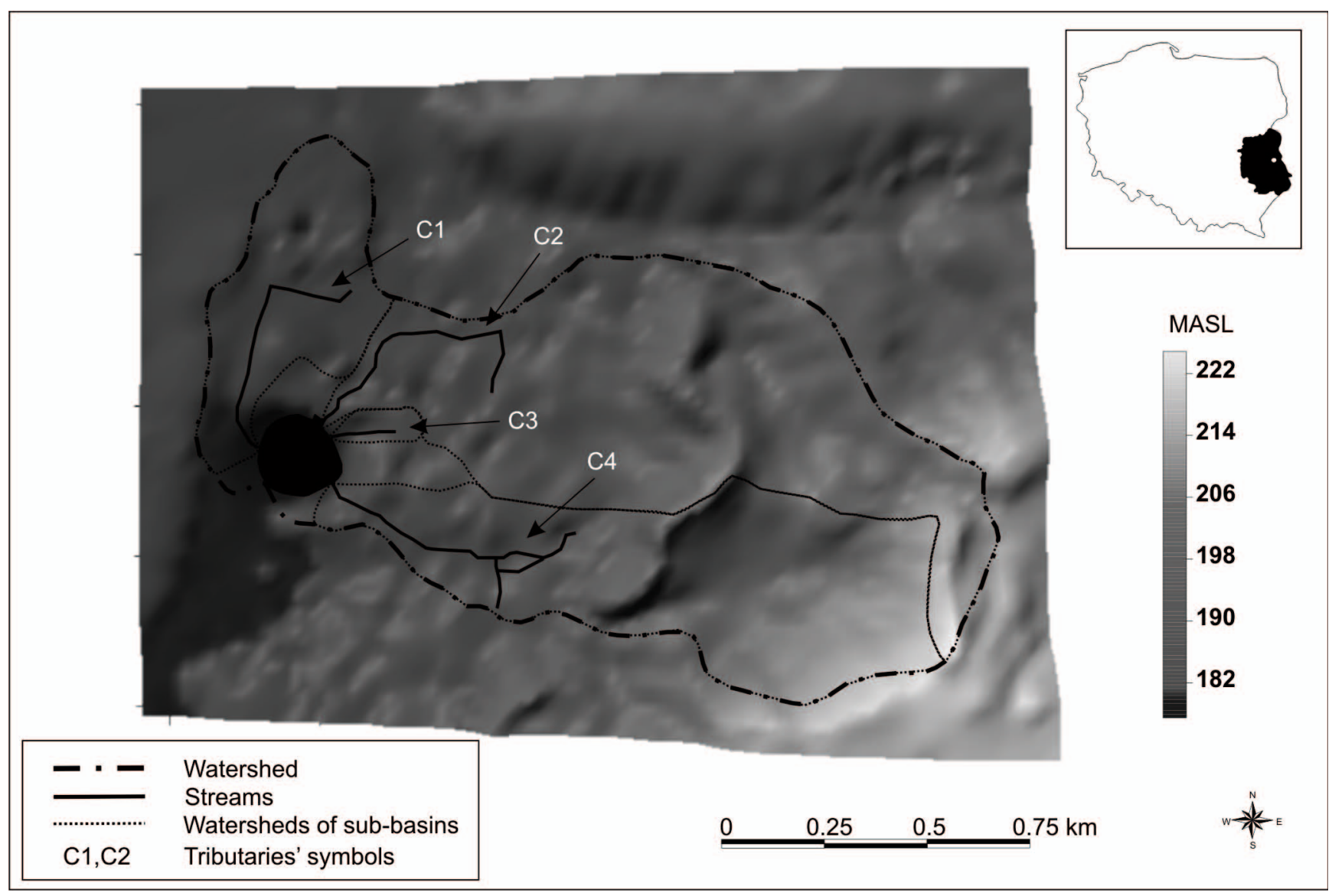

Fig. 1 Catchment area of Lake Syczyńskie (Dawidek et al. 2009) 


\section{Results}

The highest seasonal transport of suspended matter (mean seasonal ionic load) was observed in winter, whereas the lowest in summer. Spring was more important in terms of ionic translocations than autumn (Fig. 2). Taking the half-year periods into account, higher ionic load was observed in the cold periods; about $10000 \mathrm{~kg}$ sezon $^{-1}$ higher than in the warm seasons. Ionic translocation in winter and spring, as well as these in summer and autumn were similar, 33500 and $28300 \mathrm{~kg} \mathrm{seazon}^{-1}$ in summer, 11700 and $16500 \mathrm{~kg} \mathrm{seazon}^{-1}$ in winter. The areas that drained highland part of Syczyńskie catchment area (C2 and C4) dominated over sub-catchment $\mathrm{C} 1$ with respect to ionic transport, which ranged from $9107 \mathrm{~kg}$ season $^{-1}$ in summer to $13417 \mathrm{~kg}$ season $^{-1}$ in winter. The difference between spring and autumn was very small and it amounted to $10387 \mathrm{~kg}$ season $^{-1}$ and $10941 \mathrm{~kg}$ season $^{-1}$ respectively.

A dominance hydrochemical role of the perennial stream C2 was observed during the period under study. This dominance was the strongest in winter

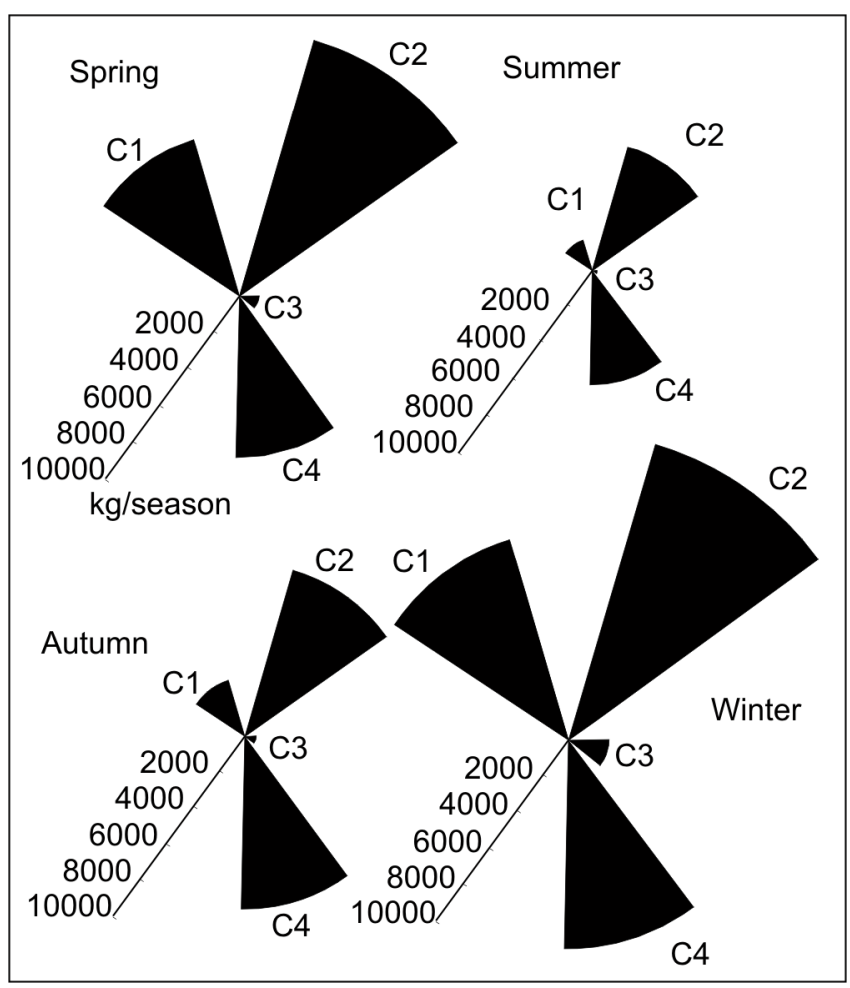

Fig. 2. Mean seasonal ionic load from the sub-catchments (C1-C4) $\left(13000 \mathrm{~kg}\right.$ season $\left.^{-1}\right)$ and in spring (11 $000 \mathrm{~kg}$ season $\left.^{-1}\right)$. The role of the smallest $\mathrm{C} 3$ sub-catchment was minimal. A matter transport from this sub-catchment was very low during all the period under study and it ranged from $143 \mathrm{~kg}$ season $^{-1}$ (in summer) to 1860 $\mathrm{kg}$ season $^{-1}$ (in winter). A quantity of ionic loads, supplying the lake from sub-catchments $\mathrm{C} 1$ and $\mathrm{C} 4$ were similar. The decrease of $\mathrm{C} 1$ sub-catchment role was observed in summer and less in autumn. The in-lake processes of ionic migration in Lake Syczyńskie basin has been shown graphically by means of vectors; length of a radius of supplying nutrients (without division to substratum). A seasonal and spatial dynamic of dissolved matter translocation was observed. The highest daily load was observed in $\mathrm{C} 2 \mathrm{sub}$-catchment (beginning from the spring) and it ranged from $17.8 \mathrm{~m} \mathrm{~d}^{-1}$ in summer to $40 \mathrm{~m} \mathrm{~d}^{-1}$ in winter (Fig. 3). A south-east part of Syczyńskie basin, supplied with waters from $\mathrm{C} 4$ stream, was very stable with regard to ionic migrations. A vector of supplying nutrients length varied from $10.73 \mathrm{~m} \mathrm{~d}^{-1}$ in summer to 20.19 $\mathrm{m} \mathrm{d}^{-1}$ in winter. A marked difference in quantity of ionic migration was typical for western part of Lake Syczyńskie basin (mouth of C1 stream). Vectors of nutrient migration in summer and autumn were very short and they did not exceeded $4 \mathrm{~m} \mathrm{~d}^{-1}$, increased to circa $14 \mathrm{~m} \mathrm{~d}^{-1}$ in spring, and exceeded $20 \mathrm{~m} \mathrm{~d}^{-1}$ in winter. A role of the basin part which was supplied with water of stream C3 was meaningless; the vector did not exceeded $5 \mathrm{~m} \mathrm{~d}^{-1}$ regardless of the season.

An influence of calculated five-day range of streams on the lake basin reached over a littoral (except of C3 stream). A strong fluviodynamic activity of Lake Syczyńskie (mean horizontal water residence time was less than a month), resulted from an intense water supply during winter and spring, which was based on the resources of surface and underground water. The lake basin alimentation with mineral matter was significantly lower in spring and autumn (Fig. 4).

The most important in shaping water quality of the lake, during the time under study, was a northeastern part of the basin, which was a recipient of water from the biggest sub-catchment. A five-day vector of nutrients migration ranged from $123 \mathrm{~m} \mathrm{pentad}^{-1}$ in summer to $148 \mathrm{~m} \mathrm{pentad}^{-1}$ in spring. Nutrients supply from the streams $\mathrm{C} 2$ and $\mathrm{C} 4$ into the basin (the longest five-day radius amounted to $148 \mathrm{~m} \mathrm{pentad}^{-1}$ in spring and $113 \mathrm{~m} \mathrm{pentad}^{-1}$ in winter respectively), decided of a dominance of the eastern sector of the basin in mineral matter supply. The lowest hydrochemical 


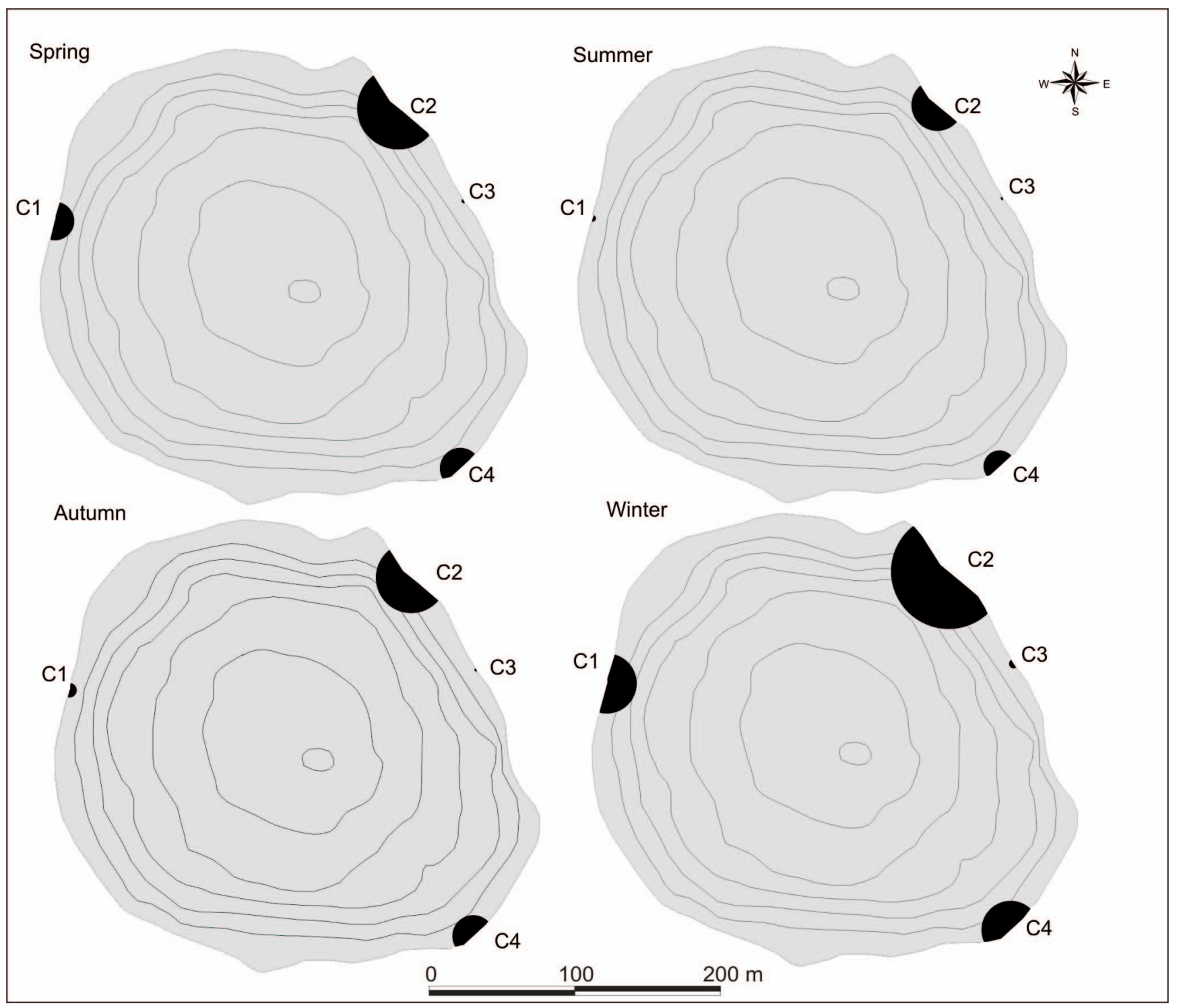

Fig. 3. Mean daily radiuses of ion translocations in Lake Syczyńskie basin

activity of streams $\mathrm{C} 1$ and $\mathrm{C} 4$ was observed in summer and autumn, while the activity of C3 stream was very low all over the year (from 3.2 to $23.7 \mathrm{~m}$ pen$\left.\operatorname{tad}^{-1}\right)$. The largest annual amplitude of ionic migration was observed in $\mathrm{C} 1$ stream, which five-day radiuses of translocations ranged from $9.2 \mathrm{~m} \mathrm{pentad}^{-1}$ in summer to $131 \mathrm{~m} \mathrm{pentad}^{-1}$ in spring.

\section{Summary and conclusions}

A quality of water in Lake Syczyńskie was determined by ionic translocation. A mineral matter was mainly transported conventionally with water, in accordance to water flow velocity. Shallow Lake Syczyńskie (max. depth $3.12 \mathrm{~m}$ ), with low volume $\left(98000 \mathrm{~m}^{3}\right.$ ) and high ratio of water exchange, could be classified as a transit water body, its possibilities to shape basins' quality parameters were very low. Both, filtration and infiltration of water in sub-catchment areas (except of $\mathrm{C} 1$ ) were fast, due to the significant hydraulic gradients and high silicate rocks permeability, which built catchment aeration zone. In the upper, eastern part of the catchment area, water circulation was characteristic for fractured-porous mediums. This 


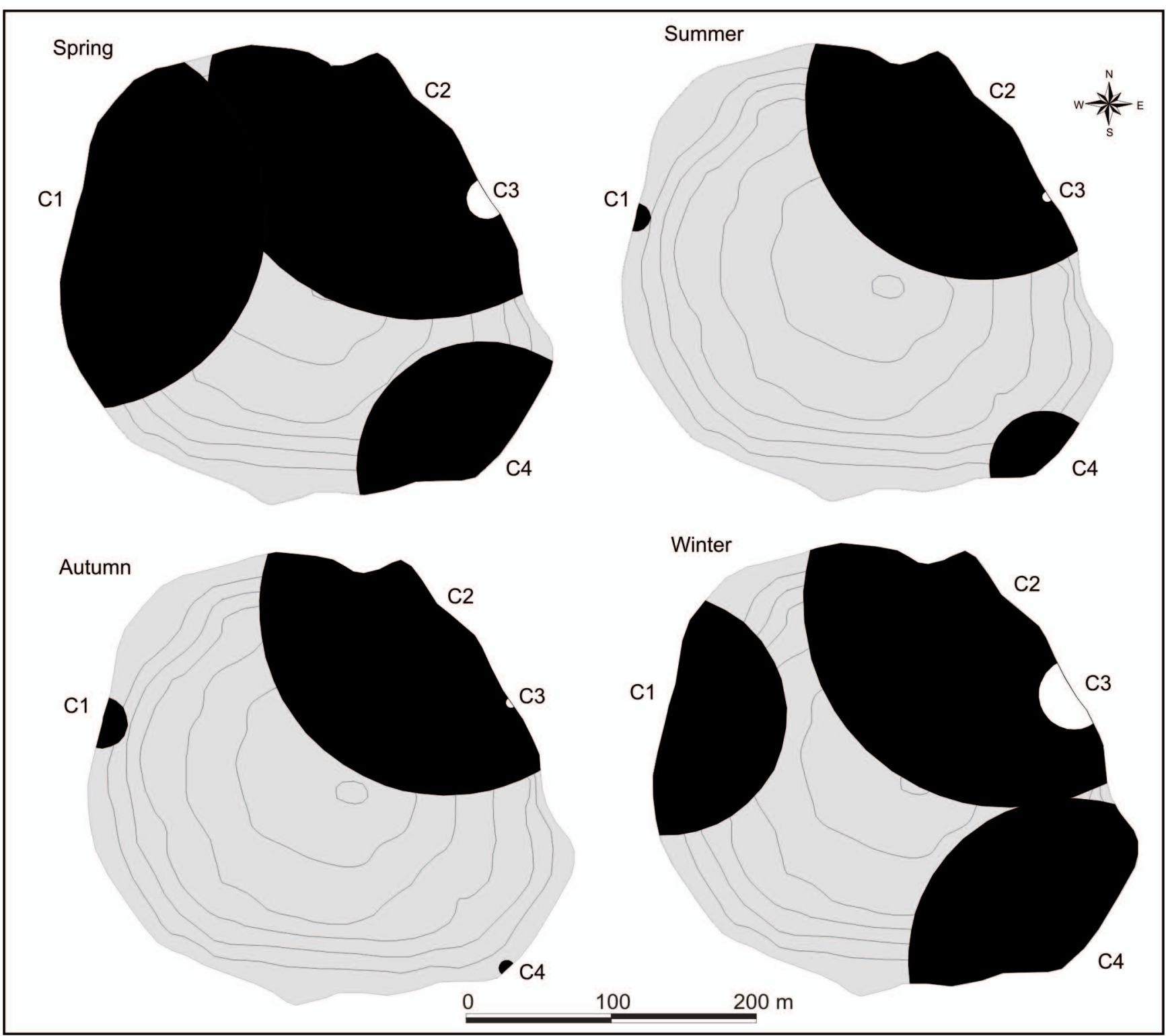

Fig. 4. Mean five-day radiuses of ion translocations in Lake Syczyńskie basin

type of circulation was typical for cretaceous rocks in Polesie (Wilgat 1998). During the time under study, the sub-catchments $\mathrm{C} 2$ and $\mathrm{C} 4$ that drained mesoregion of Chelm Hills played the most important role in ionic translocation processes. The differences in ionic loads between 'highland' and 'Polesie' areas were very stable and they amounted to $10000 \mathrm{~kg}$ season $^{-1}$. The sub-catchment of ephemeral C3 stream (despite disturbed water supply and sewage disposal) was less important in terms of nutrients transport. An ionic migration in the lake basin was shaped by fluviodynamic of $\mathrm{C} 2$ and $\mathrm{C} 4$ streams, mainly by quantity and predominant direction of dissolved matter supply. In zones of the lake basin, in which water quality was shaped by streams C2 and C4 (invariable range of ionic migration), very stable hydrochemical conditions were observed in all seasons. A significant fluctuation of ionic load from the catchment area and length of matter transport radius were observed in low-laying sub-catchment of the stream C1. A seasonal increase of ionic load from this sub-catchment resulted from anthropogenic transformations of the natural water conditions. A release of accumulated in biomass nutrients was observed during the periods of high water al- 
imentation, as a result of cretaceous peat bog drainage. In seasons, when degraded peat bog was over flooded, an intensive transport of nutrients was observed.

A comparison of five-day radiuses vectors among the lake basin zones with similar load quantities (for example range of $\mathrm{C} 1$ and $\mathrm{C} 3$ sub-catchments) showed differences of these areas. In zones with gentle slopes, (eastern part of Syczyńskie basin, mouth of stream C4), the radius of ionic transport reached further. The role of the geometry of the lake basin was the most important in spring, when hydro-geological conditions of sub-catchments determined the length of five-day radiuses. The low-laid sub-catchment (C1) was built with sediments of lower capacity; runoff of nutrients was easily formed.

\section{References}

Chałubińska A., Wilgat T., 1954, Podział fizjograficzny województwa lubelskiego (Physiographic division of Lublin Voivodeship), [in:] Przewodnik V Ogólnopolskiego Zjazdu PTG (Guide of the V National Congress of the Polish Geographical Society), PTG Lublin, Lublin: 3-44 (in Polish).
Dawidek J., Pęczuła W., Ferencz B., 2009, The role of catchment and in-lake processes in shaping trophic conditions of the shallow lake Syczyńskie (Eastern Poland). Ecohydrol. Hydrobiol. 9 (2-4): 193-200.

Hwang Y.H., Liou C.F., Weng I.S., 2000, Nutrient dynamics of two aquatic angiosperms in an alpine lake, Tajwan, Bot. Bull. Acad. Sin. 41: 275-282.

Nayak B.K., Acharya B.C., Panda U.C., Nayak B.B., Acharya S.K., 2004, Variation of water quality in Chilica lake, Orissa, Indian J. Mar. Sci. 33(2): 164-169.

Schwarz D., Grosch R., Gross W., Hoffmann-Hergarten S., 2005, Water quality assessment of different reservoir types in relation to nutrient solution use in hydroponice, Agr. Water Manage. 71: 145-166.

Vicente I., V. Amores V., Cruz-Pizarro L., 2006, Instability of shallow lakes: A matter of the complexity of factors involved in sediment and water interaction?, Limnetica, 25(1-2): 253-270.

Wilgat T., 1998, Wody Lubelszczyzny (Waters of the Lublin Province). Wyd. LTN, Lublin, p. 76 (in Polish).

Witczak S., Adamczyk A., 1994, Katalog wybranych fizycznych i chemicznych wskaźników zanieczyszczeń wód podziemnych i metod ich oznaczania, t. 1 (Catalogue of selected physical and chemical indicators of groundwater pollution and methods for their determination, vol. 1), PIOŚ, Warszawa, p.111 (in Polish). 